\title{
A contingency theory perspective of environmental management: Empirical evidence from entrepreneurial firms
}

\begin{abstract}
This paper examines the roles of organizational structure of decision-making and external pressure in determining the practice of environmental management. Using contingency theory, this study argues that having a decentralized structure, entrepreneurial firms are able to adapt to external pressure while implementing environmental management. The data were drawn from 106 small and medium sized firms in the United Kingdom (UK). The study found that a decentralized structure is positively associated with the practice of environmental management while external pressure from global awareness and social relationships has less impact on firms' environmental management. Interestingly, the impact of decentralized structure on environmental management is strengthened in the context of high level of technological dynamic. Overall, the findings of the study have provided some recommendations to theory and practice of environmental management especially in the context of entrepreneurial firms.
\end{abstract}

Keywords: Environmental management, decision-making, organization, entrepreneurship. 


\section{Introduction}

This paper aims to examine the alignment between organizational structure of decisionmaking and external pressure in determining the implementation of environmental management in the context of entrepreneurial firms. Although some studies argue that entrepreneurial firms develop a structure that is flexible enough to deal with adaptation and external threat (Tamayo-Torres et al., 2011), their limited experience may constrain their ability to maneuver resources for implementing environmental management (Baumgärtner et al., 2015). Their objective focuses mainly on bringing products or services to market, which may hinder the effort to consider environmental management as part of the operational process. At the same time, entrepreneurial firms are vulnerable in facing external pressure, such as change in demand, technology and regulation, due to the increased interest in environmental management. Thus, the alignment between organizational structure of decision-making and external pressure is critical for not only successful business performance but also the implementation of environmental management.

In order to bridge the gap in the literature, this study empirically analyzes how decentralized structure of organizational decision-making and external pressure such as social relationship, global environmental awareness and the dynamic of technological development influence the practice of environmental management. More specifically, this study focusses on entrepreneurial firms which is defined as small and medium sized firms aiming to bring products or services to the market by actively involved in exploring, evaluating and exploiting opportunities (Shane and Venkataraman, 2000; Acs et al., 2009). Using the contingency theory as a framework (Drazin and de Ven, 1985), this study examines the interaction among those factors in encouraging entrepreneurial firms to implement environmental management. Despite being important, few studies on environmental management have focused on firms with the decentralized structure, when the decision making has been disaggregated into a number of units, division, each making its own decisions (Siggelkow and Levinthal, 2003). Since instigating a new approach to business such as introducing environmental management requires a collective effort of the whole organization across different functional areas, firms with decentralized structure, will be at an advantage to deal with external pressure and to manage the implementation (Frondel et al., 2007; Gallear et al., 2015; Lichtenstein et al., 2017; Martin et al., 2016).

Using data from 106 small and medium sized firms in the UK, this study makes several contributions. First, this study investigates the role of organizational structure as an enabler for implementing environmental management in the context of entrepreneurial firms. It highlights 
the relevance of decision making process that has often been overlooked in studying small firms' environmental activities (López-Gamero et al., 2016). Although previous studies have been advocating the benefits and values of implementing environmental management, the understanding on the determinant factors in the context of entrepreneurial firms is still limited (Kunapatarawong and Martínez-ros, 2016; Mitra and Datta, 2014). Second, as few studies have been devoted to investigating the alignment between organizational structure of decisionmaking and external pressure, this study further advances the application of contingency theory by moving beyond management and organizational studies (Linnenluecke and Griffiths, 2010; Vroom and Philip, 1973; Weber et al., 2009) to environmental management and entrepreneurship studies. As contingency theory argues that the best way to organize is to depend on the nature of the environment to which the organization is related (Cui et al., 2014; Karim et al., 2016), the implementation of environmental management can be conceived as a product of the fit between the structure of organizational decision-making and a set of external factors. Lastly, the study aims to assist both managers and policy makers to understand more about how better policies can be designed to support the implementation of environmental policies, especially in the context of entrepreneurial firms (Johnstone and Labonne, 2009; Klassen and Angell, 1998). As there has been an increases of environmental degradation, such as depletion of natural resources and climate change, the efforts to preserve the environment (Ateş et al., 2012; Feng et al., 2014; Graham and Potter, 2015) and a new way of measuring firms' competitive advantage has arisen where environmental management should be considered as a part of firms' strategy (Gualandris and Kalchschmidt, 2016). Accordingly, entrepreneurial firms are considered to be less competitive unless they meet and follow trends in sustaining and maintaining the environment (Llach et al., 2015).

\section{Organizational structure of decision-making and external pressure: A contingency theory approach of environmental management}

As employing environmental management is a complex process, entrepreneurial firms need to align the pressure from external source with their internal organizational structure (Dahlmann et al., 2008; Ormazabal and Sarriegi, 2014). In one hand, entrepreneurial firms need to construct a decentralized structure, that is more receptive to the change due to their high degree of flexibility and freedom (King et al., 2005). On the other hand, entrepreneurial firms face pressure from global trends and competitor to implement environmental management. Additionally, customers or buyers have become critical regarding the source and process of production (Wong et al., 2020). Hence, entrepreneurial firms should be able to absorb external 
pressure while allowing adaptation and changes with their internal structure. Extant literature has been advocating the importance of having a decentralized decision-making process, which is often seen as a source of competitive advantage for entrepreneurial firms when operating in difficult environments (Luo and Rui, 2009; Martin et al., 2016). The logic is that external pressure might have a positive impact on firms if they are supported by suitable organizational structure (Brettel et al., 2015; Martin et al., 2016). By leveraging their adaptable organizational structure, entrepreneurial firms will be able absorb external pressure as a driver that eventually facilitates the diffusion of environmental management into all aspects of the organization.

This thinking is in line with contingency theory, which explains how external conditions correlate with organization's internal structure to form an organizational fit that determines their performance (Burns and Stalker, 1961; Tangpong et al., 2019). The origins of this theory can be traced back to the works of prominent scholars such as Donaldson (1987), Drazin and de Ven (1985), Thompson (1967),Venkatraman (1989). The theory upholds the belief that there is 'no one best way' of managing or organizing but it depends on the 'fit' between the organization and the environment (Schoonhoven, 1981; Venkatraman, 1989). In the context of this study, external pressures in the form of social relationship, global awareness and technological dynamic correlate with a decentralized structure to form the organizational fit that determines the effectiveness of environmental management (Aragón-Correa et al., 2008; Perez-Valls et al., 2016; McAdam et al., 2019). Figure 1 illustrates the framework of this study.

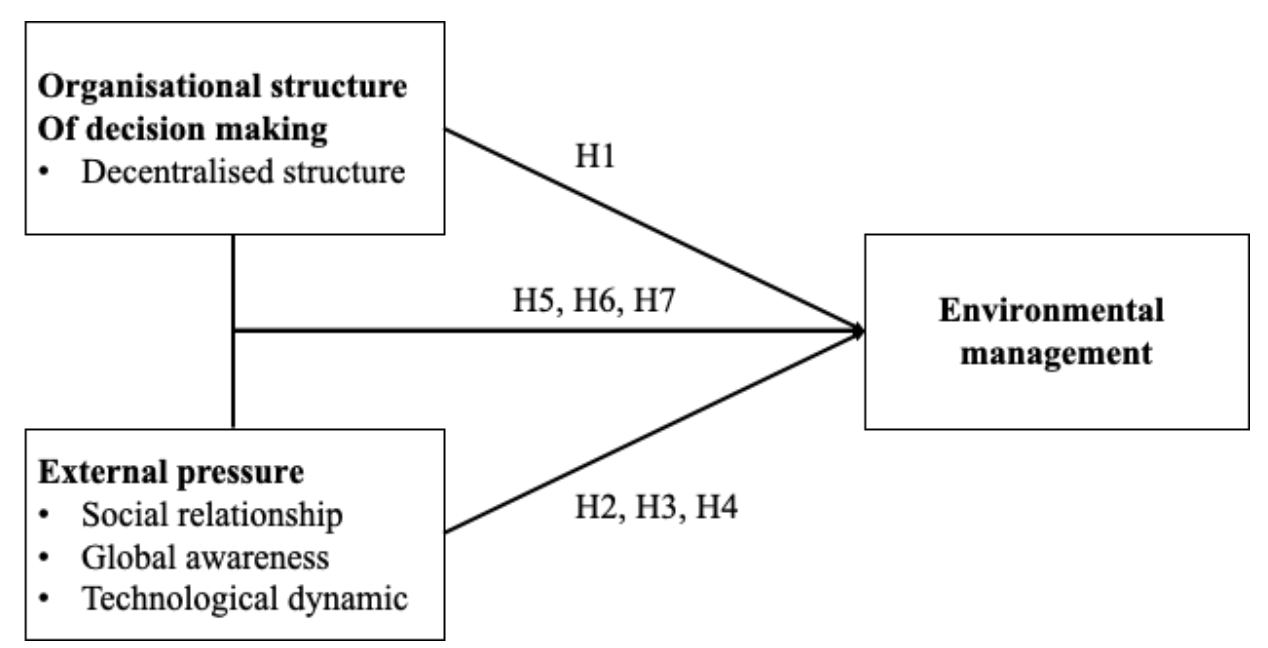

Figure 1. Research framework 


\subsection{The Construction of hypotheses}

Research on organizational theories highlights the critical role of the organizational decision-making process in enabling organizations to respond quickly to external pressure and to greater uncertainty and competition (Csaszar, 2013). As external pressures may create uncertainty and reduce profit, there is still considerable confusion as to how organizations should respond to them (Zailani et al., 2012). Within the context of decision-making, the literature has been discussing two forms of structure. First, firms create structure for decision making by developing a decentralized structure or bottom-up approach which encourages more involvement in the decision-making arrangement (Martin et al., 2016). Second, a top-down approach attempts to ease external factors through a more centralized form of organizational structure (Joseph et al., 2016).

This study argues that the implementation of environmental management in the context of entrepreneurial firms should be supported by a decentralized structure. The reason for it is because environmental management is seen as organization's voluntary mechanism of techniques, policies and routines to tackle environmental issues (Montabon et al., 2007; Wang, 2017). This includes formal standards or informal practice to reduce the negative impact on the natural environment. Unlike regulations and rules imposed through the government, environmental management is voluntarily driven; firms are not obliged to follow guidelines but are self-motivated (González-Benito, 2008). Since the implementation of environmental management involves a complex process and requires participation from workers at all levels in the firm, organizations will not be able to adapt with centralized structure (López-Gamero et al., 2016). This is because in centralized structure, organizations limit the involvement of lower level staff to participate in the decision-making process, while narrowing communication channels and creating a high level of authority (Cardinal, 2001). In contrast, a decentralized structure allows organization to implement new approaches within their traditional or normal routines. A decentralized firm by default will motivate employees to concentrate their efforts and warranted freedom to express their ideas without having to be distracted by bureaucratic hierarchy to achieve environmental performance (Hart, 1995). As the firm structure becomes more decentralized, the elements of autonomy emerge whereby lower-level staff are more regularly involved throughout the decision-making process. The less formal communication will encourage new idea developments (Narayanan et al., 2011) and expression of such an approach could lead to positive outcomes for the firm such as sustainable awareness.

Moreover, to gain employees' support, top level management needs to provide discretion to encourage contextual experimentation within the organization. Environmentally 
proactive firms would alter the pattern of authority, responsibility and control to allow operating managers to tap into the budgeted funds (López-Gamero et al., 2016). This provides space for them to reconfigure while exploring the whole new routine as a result of applying environmental management. In that case, besides improvement of environmental impact, the cost benefits and innovation will potentially be realized too (Sharma et al., 1999). In this respect, studies (Russo and Fouts, 1997) founds that firms displaying environmental behavior are characterized, among other things, as decentralized and involving higher participatory decision-making structure. Organizational commitment to the environment involves employees at various levels (López-Gamero et al., 2016), hence they are required to have decision-making authority in order to increase environmental productivity (Sweet et al., 2003). Thus, organizations such as entrepreneurial firms embracing a decentralized approach are expected to contribute to environmental strategy as stated in the following hypothesis.

\section{H1: A decentralized structure encourages entrepreneurial firms to implement environmental management.}

Another factor that encourages entrepreneurial firms to implement environmental management is pressure from external relationships. Environmental sociologists have emphasized the importance of social ties in shaping environmental practices (Hargreaves, 2016). Entrepreneurial firms learn from and are influenced by other firms in their geographical and social capital (McHugh and Perrault, 2018). As argued by Cantor et al. (2015), the engagement with environmental management practices at firm level needs be done collectively. Having another organization within their networks that implements environmental activities will put pressure on firms to follow the practices. The pressure from social relationships also applies at the individual level (Reichhart and Holweg, 2008). Among employees of firms, it is common for shared knowledge and information to happen among socially close individuals, especially interactions with those that meet on a frequent basis, such as customers, rivals and suppliers. The pandemic of environmental awareness has been proven through an increase in interest towards the environment from various groups of scholars, firms and consumers (Cho, 2014). Social relationships are responsible for the spread in awareness (Baumgärtner et al., 2015). Without the establishment of a social relationships, entrepreneurial firms may not be exposed to diverse knowledge and thus may be less motivated to pursue any environmental management strategy. Overall, it can be argued that pressure from social relationships has a positive effect on the implementation of environmental management. Entrepreneurial firms are likely to feel 
left behind if other players in their business ecosystem are following the market trend of sustainable practice.

Through early anticipation, entrepreneurial firms could act promptly by adapting certain environmental measures to ease the pressure from their network contacts. As a result, environmental management is becoming more of a response to social relationships, which, other than helping to preserve the natural environment, also acts as a tool to achieve competitive advantage and stay ahead of other businesses (Leonidou et al., 2015). The effect social relationships on the practice of environmental management yields the following hypothesis:

\section{H2: Social relationships with partners who are implementing environmental management encourage entrepreneurial firms to implement environmental management practice.}

In recent years, global environmental awareness has changed the industrial competition patterns for firms around the world (Chang and Chen, 2012). Various groups, such as political stakeholders (e.g. government), economic entities (e.g. consumers), pressure groups (e.g. nonprofit bodies) and members of the community are becoming interested in ensuring the sustainability of the environment (Bansal and Hunter, 2003; Leonidou et al., 2015). Thus, entrepreneurial firms are becoming more concerned to focus on environmental issues as a result of rising trend (Keogh et al., 2006). Among the reasons to implement environmental management include the desire: (1) to exhibit socially responsible behavior to influential entities such as governmental authorities and consumers; (2) to present a corporate image that is concerned about environmental issues; and (3) avoid negative consequences such as penalties and consumer boycotts (Banerjee et al., 2003). Hence, experiencing high pressure to become sustainable, firms have no choice but to adapt to the situation (Walker et al., 2014). Flammer (2013) argued that as environmental issues become institutionalized as a norm, the stronger the effect of negative perceptions of a firm, and firms who are not following the norms will be punished.

The rise in global environmental awareness has also changed consumer behavior rapidly (Wang et al., 2014). Follows and Jobber (2002) reported that initially, very few environmentally responsible products were available in the market. However, the existence of such products in the market are signs that consumers are more aware of the sustainable issues and want to be part of the solution to the problem. Previous studies (e.g. Purhoit, 2012; Zhang et al., 2015) found that the majority of North American consumers have environmental 
concerns over the products that they buy. This increase in demand towards environmentally responsible products has resulted in the form of pressure for firms to employ environmental management (Cho, 2014). Consumers have acknowledged the importance of environmental issues and therefore tend to boycott companies conducting unethical environmental activities (Chang and Chen, 2013). To conclude, global environmental awareness can be considered as an influencer for firms to implement environmental management (Pacheco and Dean, 2015). Thus, the study posits the following:

\section{H3: Global environmental awareness encourages entrepreneurial firms to implement environmental management.}

Over time, industrialization has compromised living conditions through uncontrolled pollution (noise, water and air) and unsafe machinery (Wong et al., 2012). However, over the last few decades, efforts through technological development were being made to avoid more environmental destruction of the natural environment. Technology is also another factor that may help entrepreneurial firms to implement environmental management. Not only does technological advancement create sustainable products, but firms also undergo a whole new process of operation that considers how to avoid negative impacts towards the environment (Ogbeibu et al., 2019).

The dynamic in the development of technology is defined as a rate of change of product and process technologies used to transform inputs into outputs (Jaworski and Kohli, 1993). This study argues that technological dynamism will facilitate the creation of environmentally friendly products and might have a positive impact on firms' environmental management. For example, in markets for high-tech products namely semiconductors and mobile telecommunications, the technology is evolving rapidly (Chang and Chen, 2013), which encourages the usage of advanced technology with sustainable features such as energy saving and reduced pollution effects. Moreover, the latest innovation practices are now more sensitive towards issues of environmental protection such as energy saving and wastage. In contrast, firms with less focus on innovation and technological dynamism will potentially suffer from obsolescence of existing products due to the rapid and constant redefinition of consumers' preference structure (Suarez and Lanzolla, 2005).

The fast-changing technological development could also affect operations in general through advanced machinery with environmentally friendly routines, which can help to support firms' ethical stance towards environmental initiatives (Ogbeibu et al., 2019). Based on the 
need to remain competitive, innovation can be an option for firms to survive and grow. It determines whether the firm will grow through applying the updated technology or decline due to obsolescence of existing technologies. Rapid innovation cycles also create more opportunities to build machinery involving processes of transforming inputs into outputs with environmentally friendly features (Chen et al., 2015). Therefore, the following hypothesis is constructed:

\section{H4: Technological dynamics encourage entrepreneurial firms to implement environmental management.}

The theoretical position underlying this study is that alignment between organizational structure of decision-making and external pressure is a desirable property that has implications for performance (Olson et al., 2005; Venkatraman, 1990; Vorhies and Morgan, 2003). The expectation is that entrepreneurial firms should reconcile these competing forces to effectively implement strategy. In other words, the success of environmental management is contingent on the ability of firms' internal structure of decision making to adapt and accommodate pressure and threat from external factors. External factors in this study includes social relationship, strong global awareness on environmental management and technological dynamics that should encourage firms to invest in building critical capability to deploy effective combinations for generating competitive outcomes (Zhao et al., 2018).

The next hypothesis argues that the implementation of environmental management is strengthened by alignment between a decentralized structure and external pressure from social relationships. As network partners share their unique ways of practicing environmental initiatives, the diffusion of environmental management practices increases. In the context of entrepreneurial firms with decentralized structures, firms authorize lower employee levels to make their own decisions. This enhances employees' awareness about environmental management, and they can potentially gather information as a result of their social relationship with other business actors who practice environmental management (e.g. customers, suppliers and competitors). The continuous interaction among business actors can catalyze the development of cooperative norms which therefore support the environmental management practices (Bercovitz et al., 2006). In contrast, in less decentralized firms, a firm's perspective is narrowed to a few top decision makers and limits alternative perspectives (Martin et al., 2016). As the ideas about environmental solutions for the firm must be endorsed by the higher level of authority before the implementation, a centralized structure may weaken the 
implementation of environmental management. Based on the argument, this study assumes the interaction between social relationships and a decentralized structure will encourage the practice of environmental management. Thus, the hypothesis is constructed:

\section{H5. Social relationships with partners who are practicing environmental management strengthens the impact of having a decentralized structure on the implementation of environmental management.}

In the context of forms with centralized structure of decision-making, the pressure from global trend and awareness on environmental responsiveness would be less effective in forcing entrepreneurial firms to implement environmental management practices (López-Gamero et al., 2016). Due to the unpredictable environmental awareness in the market, as well government pressure for businesses to operate with lower impacts on the natural environment, adapting to market demands and trends may be delayed due to the communication and agreement that needs to be transmitted across certain functional levels before actions are executed (Joseph et al., 2016). In some cases, the decision is limited only to higher ranked executives. In this matter, the longer the time it takes for the firm to execute environmental practices, the higher the chance that they will lose their competitive advantage. In contrast, a decentralized structure will allow entrepreneurial firms to react quickly and flexibly enough to deal with global awareness on the environment and environmental issues (Agrawal, 2014). Global environmental awareness has forced entrepreneurial firms to explore the possibility of embedding sustainable elements in their business practices while adjusting their strategic planning accordingly (Buysse and Verbeke, 2003). With the exponential growth of concern for the natural environment globally, firms that practice environmental management are more likely to portray their business as supporting global sustainable agendas (Gadenne et al., 2009). Such a strategy is prevalent since a positive image could encourage business growth in the environmental era (Chang and Chen, 2013). Therefore, the following hypothesis was proposed:

\section{H6. Global environmental awareness strengthens the impact of having a decentralized structure on the implementation of environmental management.}

The next hypothesis focuses on the interaction between technological dynamics and the decentralized structure in encouraging entrepreneurial firms to implement environmental management. A fast-changing technological development offers new opportunities for 
entrepreneurial firms to implement environmental management. However, they have to react quickly. As the accelerated pace of technological changes has encouraged the innovation of environmentally friendly products (e.g. solar powered electrical equipment and electric cars) and environmental operation (e.g. less wastage, less pollution, proper waste treatment), a decentralized structure provides flexibility to develop competitiveness through innovation (Hall and Rosson, 2006). Several studies (e.g. Kim et al., 2019; Ogbeibu et al., 2019) have found that firms met environmental target outcomes due to technological dynamics. This external pressure strengthens the ability of structurally decentralized entrepreneurial firms to implement environmental management. In a decentralized structure, firms react faster (DavisSramek et al., 2015), thus, they are more effective in the practice of environmental management. Hence, the following hypothesis is constructed:

\section{H7. Technological dynamics strengthen the impact of having a decentralized structure on the implementation of environmental management.}

\section{Research method}

\subsection{Sample}

This study focuses on entrepreneurial firms defined as firms with an aim to bring new products or services to market by creating opportunities. More specifically, this study chose small to medium manufacturing firms as the target sample since their operational activities have been associated with negative environmental impacts, thus, they are increasingly pressured to act ethically by paying attention towards the environment (Delgado-Ceballos et al., 2012). The sample for this study was firms with annual turnovers of less than $£ 25$ million and/or employing fewer than 250 people, coming from a broad sweep of manufacturers in terms of the sector.

Prior to the main data collection, a pilot survey with a sample of seven entrepreneurial firms was conducted. Those respondent firms came from various sectors of manufacturing. Before the interview, the complete questionnaire was sent via email. During the process of answering the questionnaire, at least one researcher was present to capture all comments and recommendations. Based on the feedback, some parts of the questionnaire had to be paraphrased to suit the background of respondents who were not familiar with research jargon. At the same time, a panel study involving academics, such as $\mathrm{PhD}$ students and researchers from the field of management, was conducted to evaluate the questionnaire. After receiving 
feedback from the pilot survey and the panel study, some questionnaire items were adjusted to increase clarity.

The sample of this study were derived from the FAME (Financial Analysis Made Easy) database. To increase the effective response rate of the conducted survey, research assistants were employed to contact each selected company, explain the research objective and content of the survey. Furthermore, they were to gather details of the most suitable personnel from the firm to answer the questionnaire. For each firm, only a single representative was required. The survey was conducted online where the potential respondents received an invitation via email. We asked the respondents to answer the online survey within one week. In total, we contacted 2,767 small to medium size manufacturing firms; but only 1,887 invitations were sent. This was due to certain firms contacted were not interested to participate in the survey. After two follow-up contacts with non-respondents, 106 complete and valid responses were collected. The effective response rate was 5.6\% which is similar to $\mathrm{Yu}$ and Ramanathan (2015). Moreover, the sample size of this study is also comparable with the sample size from recent research on this topic (e.g. Peng and Lin, 2008; Singh et al., 2015)

\subsection{Measurements}

Table 1 provides the measurements for this study. In this study, the practice of environmental management is measured through organizational activities including operations, inbound logistics, outbound logistics, services and sales and marketing (Pal and Altay, 2019). The activities were selected based on Porter's value chain approach as representatives of generic activities that are performed to design, product, market and delivers value for customers. By covering all aspect within firms' value chain, this study aims to includes formal standards or informal practice of business to reduce the negative impact on the natural environment.

Considering that the data of this study was collected based on self-reporting, the results could be vulnerable to non-response bias and common method bias (Podsakoff and Organ, 1986). To reduce the risk, the study implemented a rigorous statistical approach to verify the reliability and validity of the study. Non-response bias was diagnosed using independent sample t-tests where analysis was performed by comparing 31 firms that responded and 31 firms that did not finish completing the survey. The data for non-responding firms was collected via Qualtrics software (online questionnaire software) which stores records of respondents that have fully responded as well as those that partially responded. The T-statistics were insignificant, concluding that non-response bias was not a major issue. 
In order to check whether the survey could lead to common method bias, a few steps were taken. First, the measurements for each construct were drawn from the extant literature, carefully designed and refined through several refinement processes. Second, anonymous responses were required in this study. The respondents were informed through a phone call, email, and questionnaire. Third, the layout of the questionnaire was not designed based on the themes, such as performance, organizational decision-making structure, etc. so that it was nearly impossible for the respondents to determine the relationship between predictor and outcome variable. Fourth, Harman's single test was performed to establish whether one single factor to account for most of the variance in the data could be identified (Podsakoff and Organ, 1986). The outcome of the test showed that there were four factors with an eigenvalue of more than one which accounted for $75.62 \%$ of the total variance. There was no single factor that could account for the majority of the covariance in the model. Overall, common method bias would not be a threat to this study. 
Table 1. The variables and measurements of this study

\begin{tabular}{|c|c|c|c|}
\hline Variable's name & Questionnaire items & Variable & Description \\
\hline $\begin{array}{l}\text { Environmental } \\
\text { management (EM) }\end{array}$ & $\begin{array}{l}\text { To what extent has your firm engaged in voluntary } \\
\text { environmental activities with: } \\
\text { - Inbound logistics } \\
\text { - Operations } \\
\text { - Outbound logistics } \\
\text { - Marketing and sales } \\
\text { - Services }\end{array}$ & $\begin{array}{l}\text { 7-point } \\
\text { Likert } \\
\text { scale }\end{array}$ & $\begin{array}{l}\text { The variable like other studies in different fields } \\
\text { (e.g. Anandarajan et al., 1998; Prajogo et al., } \\
\text { 2016) was constructed based on Porter's value } \\
\text { chain framework that covers firms' primary } \\
\text { activities. These activities included inbound } \\
\text { logistics, operations, outbound logistics, sales and } \\
\text { marketing and services. } \\
\text { Studies in EM have mostly used activity-based } \\
\text { measures to quantify environmental strategy such } \\
\text { as proactive environmental strategy and } \\
\text { environmental management practices (Ateş et al., } \\
\text { 2012; Montabon et al., 2007), However, this } \\
\text { approach limits only to certain activities. On the } \\
\text { other hand, Porter's value chain focuses on a } \\
\text { broader functional unit which are common for } \\
\text { manufacturing firms. }\end{array}$ \\
\hline $\begin{array}{l}\text { Organizational } \\
\text { structure of }\end{array}$ & $\begin{array}{l}\text { - Little action could be taken here until a supervisor } \\
\text { approved a decision }\end{array}$ & $\begin{array}{l}\text { 7-point } \\
\text { Likert } \\
\text { scale }\end{array}$ & $\begin{array}{l}\text { The variable was measured by the degree of } \\
\text { centralization-decentralization in the decision- } \\
\text { making structure. The construct was assessed by }\end{array}$ \\
\hline
\end{tabular}




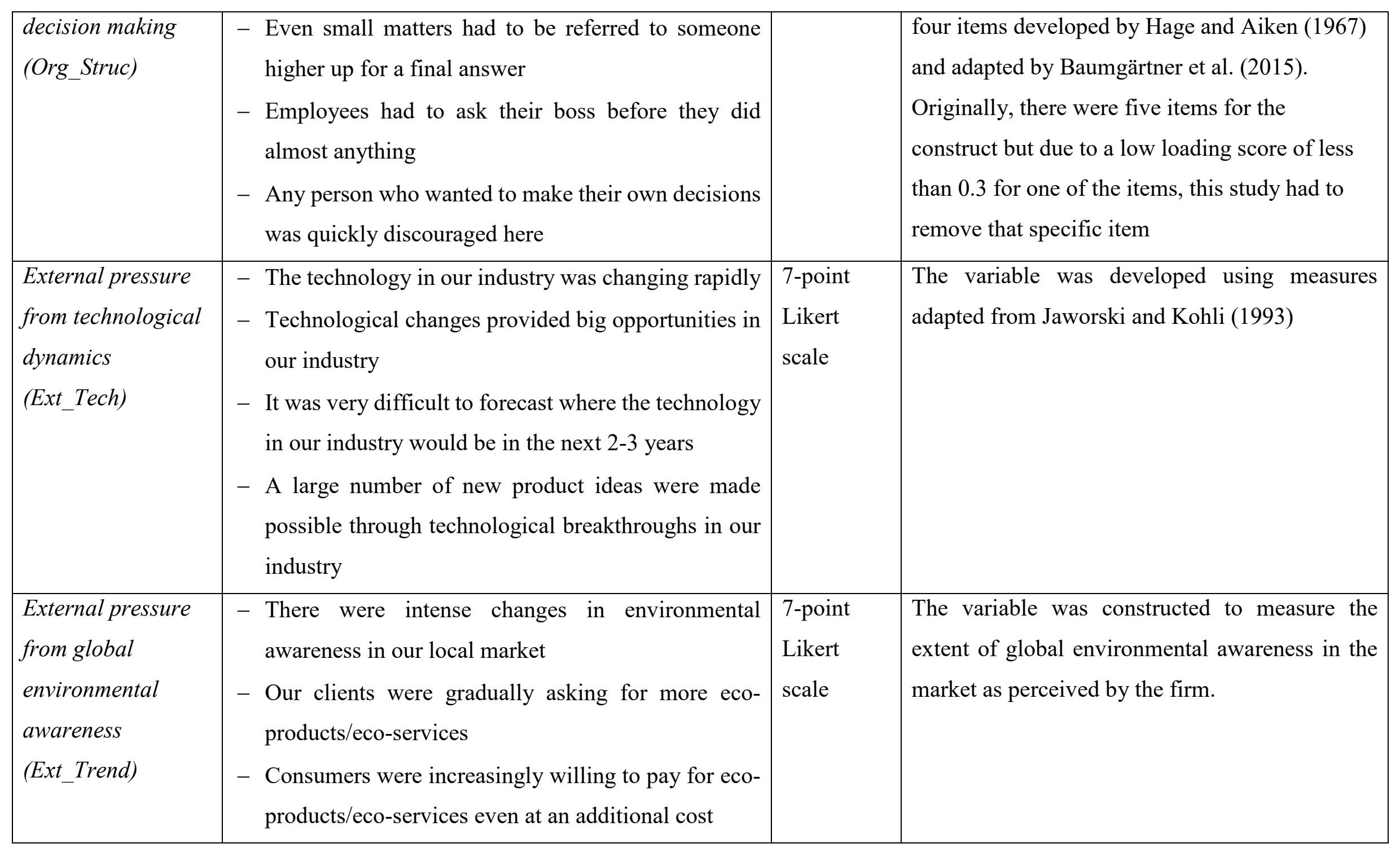




\begin{tabular}{|l|l|l|l|}
\hline & $\begin{array}{l}- \text { Each year, more and more eco-products/eco-services } \\
\text { were offered in our market }\end{array}$ & \\
\hline $\begin{array}{l}\text { External pressure } \\
\text { from social } \\
\text { relationships } \\
\text { (Ext_Social) }\end{array}$ & - We shared close social relations with them \\
& - Our relationship with them could have been defined \\
as "mutually gratifying" & $\begin{array}{l}\text { W-point } \\
\text { them far into the future } \\
\text { scale }\end{array}$ & $\begin{array}{l}\text { This variable was constructed using a } \\
\text { measurement developed by Rindfleisch and } \\
\text { Moorman (2001). This item was tested on } 4 \\
\text { different groups namely customers, suppliers, } \\
\text { rivals and other firms nearby. }\end{array}$ \\
\hline Firm size & - Firm's number of employees & $\begin{array}{l}\text { Continuous } \\
\text { variable }\end{array}$ & $\begin{array}{l}\text { The variable was measured by taking the } \\
\text { logarithm of the number of employees to } \\
\text { alleviate univariate non-normality and account } \\
\text { for non-linear effects (Feng et al., 2014). }\end{array}$ \\
\hline
\end{tabular}

Note: The Likert scale covers measurement from 1: 'strongly disagree' to 7: 'strongly disagree'. 


\subsection{Validation of constructs}

In this study, the constructs used undergo a methodologically rigorous and comprehensive examination as a fundamental for meaningful and reliable research (Trumpp et al., 2013). The first analysis was exploratory factor analysis (EFA) using principal component analysis with varimax rotation in order to examine whether the items fit with the constructs. The Kaiser-Meyer-Olkin (KMO) test for sampling adequacy was 0.76 , indicating reliability towards the constructs. The list of items was reduced to 5 factors, each with an eigenvalue of more than 1 and explains $75.62 \%$ of the total variance. Internal consistency (reliability) of the model was established through the Cronbach alpha value of more than 0.7 for each factor (Nunnally and Bernstein, 1994). Table 2 shows the indicated measures' item loadings, scale composite reliability (SCR) and average variance extracted (AVE).

\begin{tabular}{|c|c|c|c|c|c|}
\hline Items & Mean & SD & $\begin{array}{c}\text { Item } \\
\text { loading }\end{array}$ & SCR & AVE \\
\hline \multicolumn{6}{|c|}{ Organizational structure of decision making } \\
\hline Org_Struc & & & & 0.93 & 0.77 \\
\hline $\mathrm{C} 1$ & 3.61 & 1.88 & 0.89 & & \\
\hline $\mathrm{C} 2$ & 3.48 & 1.88 & 0.94 & & \\
\hline $\mathrm{C} 3$ & 3.19 & 1.95 & 0.90 & & \\
\hline $\mathrm{C} 4$ & 3.59 & 1.90 & 0.89 & & \\
\hline \multicolumn{6}{|c|}{ External pressure from technological dynamic } \\
\hline Ext_Tech & & & & 0.85 & 0.59 \\
\hline $\mathrm{T} 1$ & 4.12 & 1.68 & 0.89 & & \\
\hline $\mathrm{T} 2$ & 4.62 & 1.64 & 0.82 & & \\
\hline $\mathrm{T} 3$ & 3.71 & 1.48 & 0.59 & & \\
\hline $\mathrm{T} 4$ & 3.75 & 1.64 & 0.90 & & \\
\hline \multicolumn{6}{|c|}{ External pressure from global environmental awareness } \\
\hline Ext_Trend & & & & 0.89 & 0.68 \\
\hline G1 & 4.20 & 1.59 & 0.79 & & \\
\hline G2 & 4.28 & 1.55 & 0.88 & & \\
\hline G3 & 3.77 & 1.66 & 0.86 & & \\
\hline G4 & 3.54 & 1.67 & 0.90 & & \\
\hline \multicolumn{6}{|c|}{ External pressure from social relationship } \\
\hline Ext_Social & & & & 0.81 & 0.60 \\
\hline $\mathrm{R} 1$ & 3.86 & 1.69 & 0.75 & & \\
\hline R2 & 4.72 & 1.64 & 0.86 & & \\
\hline R3 & 4.80 & 1.67 & 0.88 & & \\
\hline
\end{tabular}

Note: SD, standard deviation

Table 2. Summary of measurement scales. 
Second, confirmatory factor analysis (CFA) to examine the reliability and validity of the measures was conducted. Table 2 shows SCR and AVE values meet the criterions (SCR > 0.7 ; AVE $>0.5$ ) that suggested the theoretical framework had established convergent validity and therefore, a reliable model. Moreover, an inter-construct correlation was calculated (Fornell and Larcker, 1981). The square root of AVE for each construct was found to be greater than the inter-construct correlations proving possession of discriminant validity. Based on the measurement fit indices used to assess the goodness-of-fit of models, it was confirmed as a good overall model fit $\left(\mathrm{X}^{2}=106.97, \mathrm{GFI}=.89, \mathrm{AGFI}=.84, \mathrm{CFI}=.98\right.$, and $\left.\mathrm{RMSEA}=.05\right)$.

\section{Findings}

This study adopts the procedures of negative binomial regression (NBR). Since the dependent variable (environmental management) was a continuous variable, employing the ordinary least squares (OLS) was not appropriate for two reasons (Gardner et al., 1995). First, the nature of the data would produce nonsensical, negative predicted value. Second, it is unlikely for count data to meet the assumptions on variance of scores. The data was not rescaled into sub-groups to avoid dilution in statistical power. Since data for the dependent variable was over dispersed and not able to meet the restriction assumptions of Poisson regression (i.e. mean=variance), negative binomial regression was employed (Hausman et al., 1984). This regression embeds a random term to reflect the unexplained between subject disputes (Gardner et al., 1995).

Table 3 depicts the means, standard deviation and correlation among the variables assessed in this study. Computation of correlation indicated multicollinearity is not a concern where the highest correlation coefficient is 0.32 (between external environmental awareness and number of employees). Since the values are below the usual threshold, it implies that no serious multicollinearity problems were in existence (Hair et al., 1998). For robustness purposes, eight models were used to address all hypotheses challenged in this study (Table 3 ). Model 1 contains the control variable and main effects. The moderating variables were added into model 2. Models 3-8 were employed to test individual interactions with the control variable and main effects. 


\begin{tabular}{lllllcccc}
\hline Variables & Mean & SD & 1 & 2 & 3 & 4 & 5 & 6 \\
\hline 1. EM & 20.12 & 7.61 & 1 & & & & & \\
2. Firm size & 96.09 & 86.91 & $.28^{* *}$ & 1 & & & & \\
3. Org_Struc & 3.47 & 1.73 & -0.28 & 0.05 & 1 & & & \\
4. Ext_Tech & 4.12 & 1.44 & $.23^{*}$ & 0.02 & $-.20^{*}$ & 1 & & \\
5. Ext_Trend & 3.75 & 1.35 & 0.17 & $.32^{* *}$ & 0.11 & 0.14 & 1 & \\
6. Ext_Social & 4.46 & 1.40 & 0.18 & 0.04 & -0.08 & 0.12 & 0.18 & 1 \\
\hline $\mathrm{N}=106 ;{ }^{*} \mathrm{p}<0.05 ; \mathrm{p}<0.01$ & & & & & & &
\end{tabular}

Table 3. Descriptive statistics and correlation coefficients

Table 4 shows the results of the regression analysis. The independent variable and moderating variables were mean centered prior to running the regression analysis to minimize potential multicollinearity problems (Aiken et al., 1991). Based on the results, the control variables (firm size) were found not to have any significant effect on firms' environmental management implementation level. Organizational structure of decision-making (decentralization) is found positively related to environmental management $(\mathrm{P}<0.01)$ in all models. This further suggests that the baseline for this study $(H I)$ is confirmed. Prior to testing the moderation hypothesis, Hypotheses 2, 3 and 4 were tested. The results from Table 4 show that all three-hypotheses failed to establish a significant relationship, thus $H 2, H 3$ and $H 4$ were rejected. Results indicated that the interaction between external pressure from social relationship and a firm's decentralized structure on environmental management was not significant $(p>0.05)$, confirming the rejection of H5. The interaction term between global awareness and a firm's decentralized structure on environmental management is significant $(p<0.05)$ but showing the opposite magnitude of what had been proposed, thus rejecting $H 6$. However, in support of $H 7$, the study confirms the positive moderating effect of external pressure from technological dynamics on the relationship between firms with a decentralized structure and environmental management. The coefficient of the interaction variable is significant $(p<0.05)$. Summary of findings are presented in table 5. 


\begin{tabular}{|c|c|c|c|c|c|c|c|c|}
\hline Variables & Model 1 & Model 2 & Model 3 & Model 4 & Model 5 & Model 6 & Model 7 & Model 8 \\
\hline \multicolumn{9}{|l|}{ Main effects } \\
\hline Org_Struc & $-0.228 * *$ & $-0.225 * *$ & $-0.218 * *$ & $-0.229 * *$ & $-0.231 * *$ & $-0.236 * *$ & $-0.266 * * *$ & $-0.23 * *$ \\
\hline Ext_Social & 0.131 & 0.156 & 0.119 & 0.14 & 0.153 & 0.148 & & \\
\hline Ext_Trend & 0.076 & 0.095 & 0.081 & 0.07 & 0.094 & & 0.125 & \\
\hline Ext_Tech & 0.155 & 0.117 & 0.152 & 0.144 & 0.134 & & & $0.166^{+}$ \\
\hline \multicolumn{9}{|l|}{ Interaction effects } \\
\hline Org_Struc x Ext_Social & & 0.024 & 0.035 & & & 0.035 & & \\
\hline Org_Struc $x$ Ext_Trend & & $0.115^{*}$ & & $0.111^{*}$ & & & $0.113^{*}$ & \\
\hline Org_Struc x Ext_Tech & & $-0.136^{*}$ & & & $-0.121 *$ & & & $-0.103 *$ \\
\hline \multicolumn{9}{|l|}{ Control } \\
\hline Firm size & $0.005 * *$ & $0.004 * *$ & $0.005 * *$ & $0.005 * *$ & $0.004 * *$ & $0.005 * *$ & $0.005^{* *}$ & $0.005 * *$ \\
\hline Constant & $4.025 * * *$ & $3.935 * * *$ & $4.032 * * *$ & $3.997 * * *$ & $3.966 * * *$ & $4.032 * * *$ & $3.997 * * *$ & $3.974 * * *$ \\
\hline Pseudo log-likelihood & -426.27 & -424.85 & -424.07 & -424.57 & -424.52 & -424.74 & -424.73 & -424.53 \\
\hline
\end{tabular}

Table 4. Results of Negative Binomial Regression Analysis for Environmental Management 


\section{Discussion}

The findings from regression analysis confirm the relationshop between decentralization and environmental management (H1). The result further verifies the importance of having a decentralized structure of decision-making to support the implementation of environmental management practice (Olson et al., 2005; Theodosiou and Katsikea 2013). The fact that entrepreneurial firms have a decentralized decision-making process, deciding and implementing a decision would require a shorter time. According to Perez-Valls et al. (2016), applying a 'flexible' organization structure would produce "aboveaverage" returns for developing environmental management. This study further tested the direct effect of external pressure from social relationships on environmental management. No evidence was found that showed a significant relationship between social relationship and environmental management. Thus, the results showed no support for $\mathrm{H} 2$. While the hypothesis is strongly supported in terms of the role of social network in influencing behavior and facilitating the sharing of information and knowledge, it might not be generalized for environmental management. Hence, more extensive research is needed to determine the other underlying factors that can help the implementation of environmental management through social pressure.

\begin{tabular}{lcc}
\hline Hypothesis & $\begin{array}{c}\text { Proposed } \\
\text { Effects }\end{array}$ & $\begin{array}{c}\text { Hypothesis } \\
\text { Supported? }\end{array}$ \\
\hline H1: Decentralized structure $\rightarrow$ EM & + & Yes** \\
H2: Social relationship $\rightarrow$ EM & + & No \\
H3: Global awareness on environment $\rightarrow$ EM & + & No \\
H4: Technological dynamics $\rightarrow$ EM & + & No \\
H5: Decentralized structure * Social relationship $\rightarrow$ EM & + & No \\
H6: Decentralized structure * Global awareness on & + & No* \\
environment $\rightarrow$ EM & & \\
H7: Decentralized structure * Technological dynamics $\rightarrow$ EM & + & Yes* \\
\hline
\end{tabular}
$* \mathrm{p}<0.05 ; * * \mathrm{p}<0.01$

Table 5. Summary of Findings

Moreover, the findings showed no relationship between global environmental awareness and environmental management which rejects the proposition of H3. Historically, environmentally friendly products have been associated with low quality products (Bourn and Prescott, 2002). While there is also a concern about an increasing trend on environmental issues (De Jong et al., 2018), entrepreneurial firms may not be interested in applying environmental management. Furthermore, environmental management can be easily overstated as Aragón- 
Correa and Rubio-López (2007) illustrated that while sales of organic food have increased by a very high percentage, it still holds a small share compared to the increase in the total food industry growth. These factors potentially drive firms away from the implementation of environmental practices. The relationship between technological dynamics and environmental management was also proven to be statistically not significant. Thus, H4 was rejected. During periods of high technological dynamics, most firms are pressured to follow the latest technology. However, certain firms do not benefit from adapting to the latest technological development, especially for products that have been available in the market for a long period of time or have been developed strong market penetration (Chang and Park, 2013).

The results reveal that social relationship does not moderate the relationship between decentralized structure of decision-making and environmental management (H5). One explanation could be that adoption of environmental strategies are more institutionally driven compared to inter-firm influences. Such actions are influenced by the need to comply with regulatory control of the institutional environment (Cummings, 2008). In any business entity, the sources of information and knowledge are carefully verified. Social relationship may not be the best source for advice or knowledge on matters concerning the environmental strategy of a firm. H6, which states that external pressure from global environmental awareness has a positive moderating effect on the relationship between decentralized structure of decisionmaking and environmental management, is not supported but resulted in a significant opposite finding $(\mathrm{P}<0.05)$. This intriguing and somewhat counter intuitive result provide a new view on how firms should react during uncertainty. The idea of critical strategic thinking, and not focusing on where the trend sits (industrial players heavily and explicitly implementing their environmental strategy), is crucially important to why a focus on strategic renewal should be considered by firms. Due to the influx of key players focusing on sustainable approaches, it no longer provides a competitive advantage platform in the long run. The contemporary global trend which is paying more attention towards environmental awareness can sometimes be tough due to the establishment of new regulations (Zhang et al., 2019) and standards, which could burden businesses that wish to venture into environmental management. For example, environmental standards, such as ISO 14001, are recognized world-wide, could improve corporate reputation (Jiang and Bansal, 2003). However, the adoption of such a standard is related to excessive bureaucratization required by the system (Ferrón, 2017).

The latest hypothesis predicted a positive moderating effect of technological dynamics on the relationship between decentralized structure of decision-making and environmental management. The results indicate that this two-way interaction is significant $(p<0.05)$ as 
shown in models 2, 5 and 8, and hence, $\mathrm{H} 7$ is supported. In the context of firms with decentralized structure, non-hierarchical autonomy encourages quick decision making based on local information or knowledge to deal with challenges of fast changing technologies (Chen et al., 2015). The result suggests that a 'fit' organizational structure of decision-making is needed to match contingency to ensure firms' effectiveness in implementing environmental management. Firms with a centralized structure are more effective in influencing environmental practices when the technological dynamics are minimal, while a high level of technological dynamics would encourage firms with a decentralized structure to strongly implement environmental practices.

To gain further insight into the nature of the two-way interaction, the interaction effect of the hypotheses 6 and 7, were illustrated (Dawson, 2014). When testing for hypothesis 6, both plots are sloping downwards, revealing that firms without a flexible structure have a negative effect on environmental management despite the presence of global awareness (figure 2). However, low global awareness shows a stronger negative effect on the relationship (decentralization-environmental management) compared to high global awareness on the environment. For the hypothesis 7, the predicted values of environmental management were calculated under different conditions (high and low values of decentralization, and high and low values of technological development). Based on Figure 3, the positive effect of decentralization on environmental management is stronger in firms with a high level of technological development in the industry compared to a lower level.

Figure 2. Global environmental awareness as a moderator of the relationship between decentralization and environmental management 


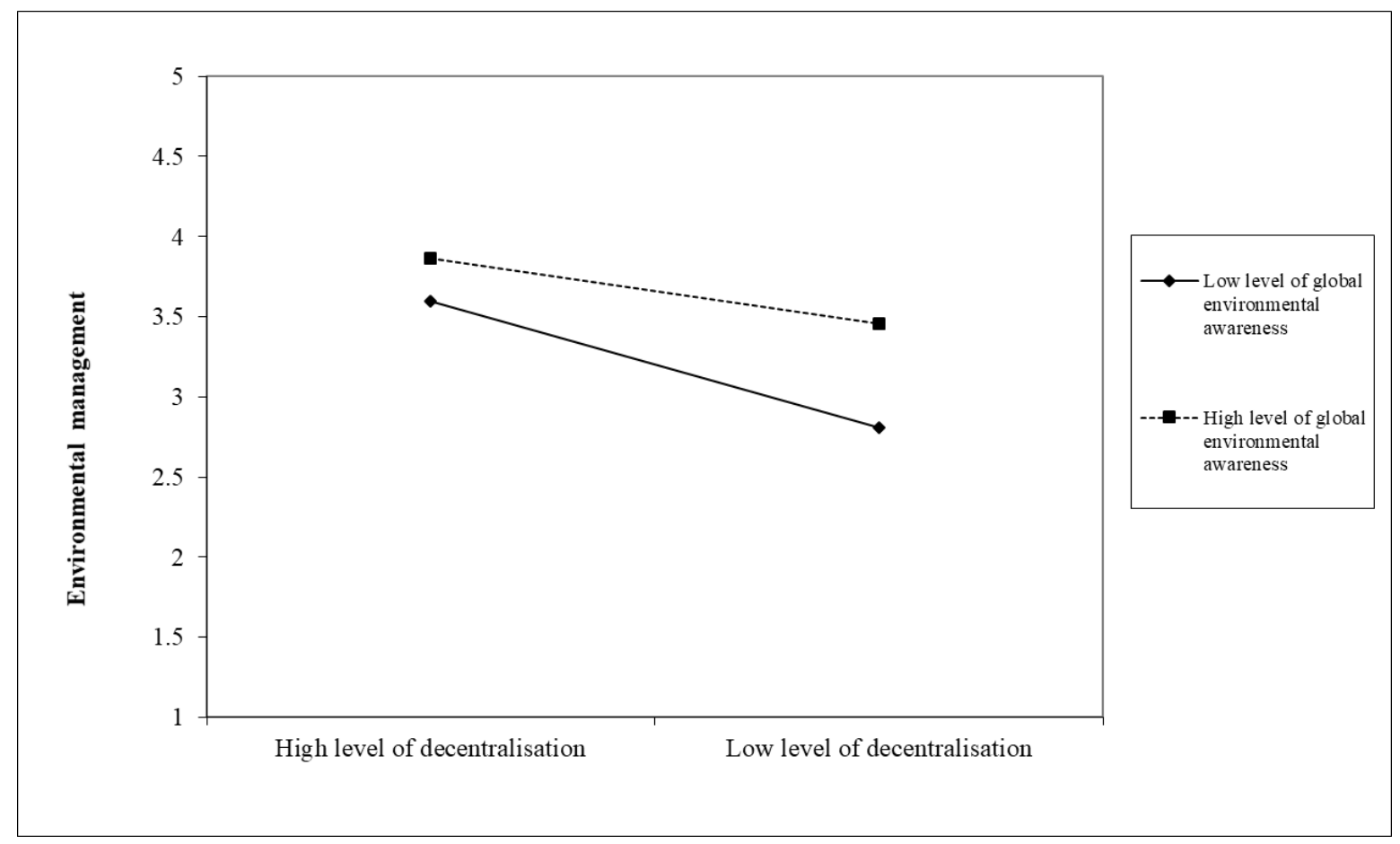

Figure 3. Technological dynamics as a moderator of the relationship between decentralization and environmental management

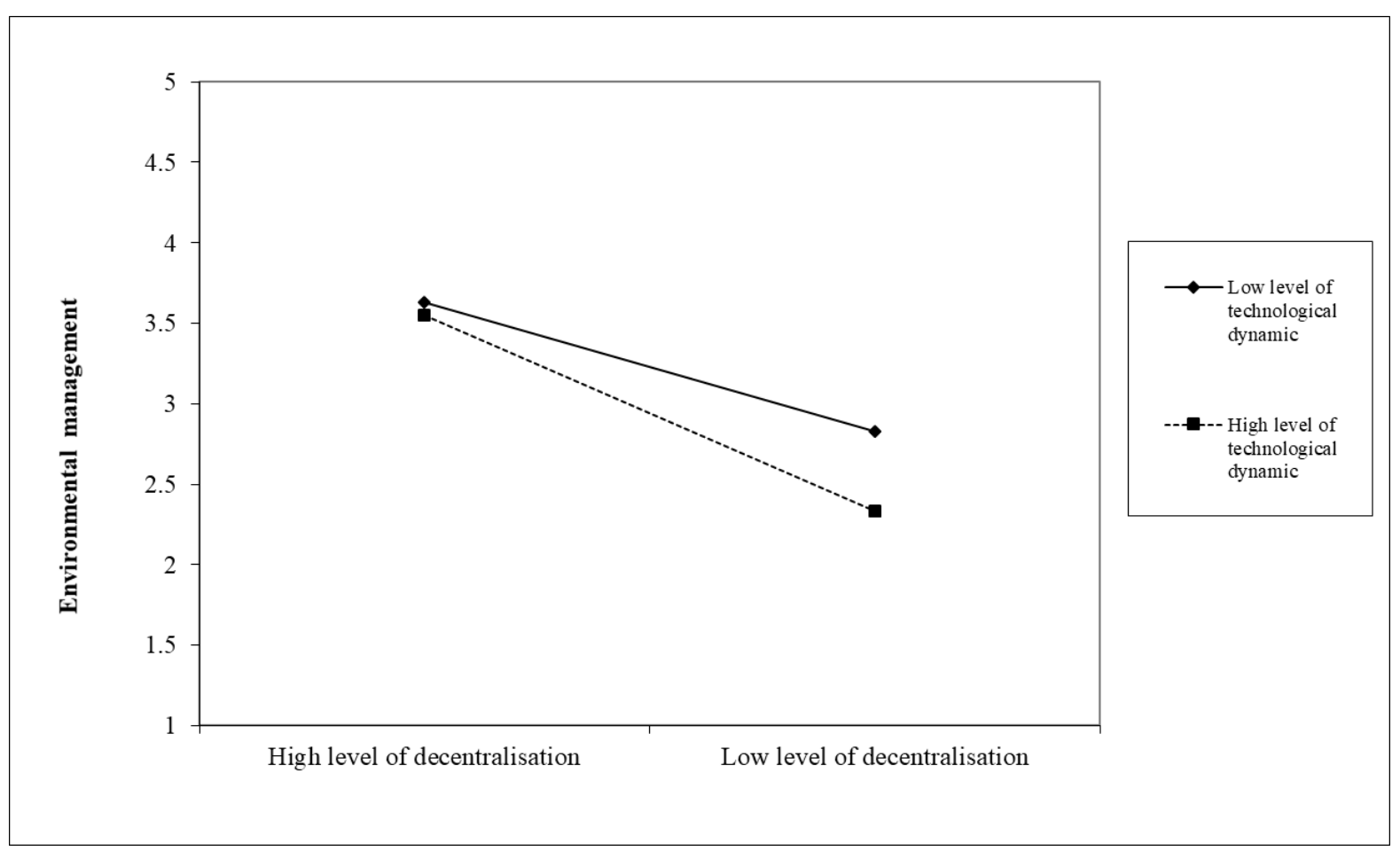

\subsection{Contribution to theory}


This study aims to examine how entrepreneurial firms with decentralized structure of decision-making are more likely to affect environmental management in situations of high external pressure. This study makes a number of contributions to theory. First, the role of organizational variables such as decentralization have been adapted widely within the management research generally (Karim et al., 2016) but has received little insight within the specific context of environmental management (López-Gamero et al., 2016). Integrating the perspective of contingency theory, this study developed a new model for this relationship, which was further tested empirically. From the findings, the baseline relationship between decentralization and environmental management was confirmed, thus, verifying previous research that argue the important role of organizational structure of decision-making on firms' performance (Boso et al., 2013). Furthermore, the findings is in-line with the concept of contingency theory that argues the optimal course of action and good fits is contingent upon the internal and external situation (Zhao et al., 2018). A key lesson from the finding may be that an individual employee's role at all levels to support an organization's policy on environmental management is important. Thus, as Quirin and Bower (2006) suggest, impetus for any firms usually begins from the lower levels of the organization, which reflects the importance of autonomy. On the other hand, it also shows that non-owners (e.g. employees) have concern over protecting the natural environment though not necessarily as part of the company's main objective. At this level of finding, it can be suggested that there is a possibility that environmental strategies are motivated and self-driven at any level of the command chain.

Second, this research extends the existing contingency theory into the context of environmental management. A key premise to this theory is that firms actions are influenced by forces from external environments (Boso et al., 2013). The extant literature has approved the role of external influence towards environmental management (Menguc et al., 2010). On the other hand, scholars have also argued the need for firms to align current practice with its environment to obtain superior performances (Karim et al., 2016). By conceptualising external factors and environmental management as multidimensional constructs, this study allows us to develop a comprehensive model and theory investigating the impact of organizational structure of decision-making on environmental management.

Third, by focusing exclusively on a firm's primary activities, the implementation of environmental management in the context of entrepreneurial firms has a better chance of receiving the most accurate information. Previously, most studies used activity-based measures (i.e. Delgado-Ceballos et al. 2012; Gallear et al. 2015) to benchmark environmental management. The items included may be insufficient and deprive certain aspects of 
environmental management that were implemented specifically by firms. From another perspective, there is no consistency in terms of the items used to measure environmental management. Using Porter's value chain (Porter, 1985) promotes consistency through the standardized activities covering all elements of environmental management practices throughout business facilities.

The next contribution focuses on the finding of this study. Going against the predicted outcome, the results showed an unusual result regarding the interaction between firms with decentralized structure of decision-making and global environmental awareness. This evidence provides a stronger basis that entrepreneurial firms tend to weigh-in the risks before committing to any "trending" strategies. A strong global pressure does not always influence firms to be environmentally proactive, since other industrial players will follow the same strategy as well as issues with uncertain benefits to the firm after engaging with environmental management practices (Ferrón, 2017).

Lastly, while most of the previous research applies a single-level approach to environmental management studies (Chen et al., 2015), this study contributes to the environmental management literature by proposing a cross-level framework that bridges the organization-level variables and the environment-level variables. Due to the increased attention on sustainability issues, this study responses to the call for more research should be devoted to explore the role of multi-level variables in supporting environmental management (Rousseau, 1985).

\subsection{Managerial implications}

Practically, the research outcomes provide beneficial implications that could lead to valuable insights for entrepreneurial firms. First, firms may often be in dilemma as to which structure (centralized or decentralized) they need to adopt to improve their environmental management. This study examines the fundamental issue addressing the organizational "fit". The framework of this study delivers some direction to managers, especially environmental managers, on how having an organizational structure orientation may translate into specific environmental proactivity within the context of entrepreneurial firms. Since there is a complex decentralization-environmental management relationship linked to exogenous uncertainties, managers can therefore make informed decisions about their strategy (López-Gamero et al., 2016). Unlike other strategies, environmental management initiatives are challenging (Lucas and Noordewier, 2016), needing firms to consider organizational design such as organizational 
structure of decision-making. As such, firms are warranted to align the structure of decision making in order to ensure that they can implement environmental management.

Second, firms usually face difficulties in determining to what extent they should be committing to environmental practices to gain market position. This study shows that even when there is high external pressure for firms to engage with sustainable practices, those entrepreneurial firms are better-off not to focus intensively on environmental management. Many studies have found negative relationships between corporate environmental management practices and financial performance (Aragón-Correa and Rubio-López, 2007). The general overclaims that encourage firms to practice environmental management for financial gains have increased confusion around this topic and in some cases, might lead towards disappointment which drives firms away from having an interest in practicing environmental management within their business. Furthermore, there are findings that the environmental statements and claims made by companies are not always trusted by stakeholders (AragónCorrea and Rubio-López, 2007). On the consumers' side, not all citizens have equal interest in every aspect of environmental preservation. This makes it riskier for firms implementing environmental practices that may have the least interest for their target market. Strategically, firms must analyze and conduct their due diligence and prepare their organization before deciding on any environmental management decisions.

Third, in cases of high pressure from technological development, entrepreneurial firms with a decentralized structure tend to have a better interest in committing to environmental management practices compared to those that are with a centralized structure of decisionmaking. Since technological advancement can only be managed by firms that are alert and can respond faster, a decentralized structure would best fit this description. In a decentralized structure, decision-making is made by those holding the relevant information (Davis-Sramek et al., 2015) while the decision making in a centralized structure is usually in the hands of a few founding members (Martin et al., 2016). Hence, firms that are able to respond faster in an environment of high technological pressure will have strong complementary capability that helps their practices towards a more aggressive environmental goal (López-Gamero et al., 2008).

\subsection{Limitation}

Notwithstanding its contribution, this study has some limitations. First, it focuses solely on entrepreneurial firms. Though negative environmental outcomes usually relate to organizations involving production lines, other types of industry such as services were 
neglected. Since both industries have different operational settings, which could affect the natural environment in different ways, there would be a generalization problem if the study is based on a single industry. Future studies could look into the different industries, adapting the existing framework from this study to complement the results, hence generalizing the findings.

Second, in the extant literature, organizational structure is usually measured by three major structural variables, namely formalization, decentralization and standardization. While seemingly, they are supposed to form a unitary conception characterized by a highly positive relationship, there were studies that found otherwise (Child, 1972). In this study, only a single element of organizational structure was focused on, which is the degree of decentralization. Future research could therefore involve all aspects of organizational structure.

\section{Acknowledgement}

The authors would like to thank the Ministry of Higher Education, Malaysia and Universiti Putra Malaysia for the financial support that helped to fund the whole research.

\section{REFERENCE}

Acs ZJ, Braunerhjelm P, Audretsch DB, et al. (2009) The knowledge spillover theory of entrepreneurship. Small Business Economics 32(1): 15-30. DOI: 10.1007/s11187-0089157-3.

Agrawal P (2014) Effect of uncertain and turbulent environment on organizational design. Economic \& Business Journal 5(1): 11-24.

Aiken LS, West SG and Reno RR (1991) Multiple Regression: Testing and Interpreting Interactions. Sage, Newbury Park, CA.

Anandarajan M, Anandarajan A and Wen HJ (1998) Extranets: a tool for cost control in a value chain framework. Industrial Management \& Data Systems 98(3-4): 120-128. DOI: $10.1108 / 02635579810213125$.

Aragón-Correa JA and Rubio-López EA (2007) Proactive corporate environmental strategies: Myths and misunderstandings. Long Range Planning 40(3): 357-381.

Aragón-Correa JA, Hurtado-Torres N, Sharma S, et al. (2008) Environmental strategy and performance in small firms: A resource-based perspective. Journal of Environmental Management 86(1): 88-103. DOI: 10.1016/j.jenvman.2006.11.022.

Ateş MA, Bloemhof J, Van Raaij EM, et al. (2012) Proactive environmental strategy in a supply chain context: The mediating role of investments. International Journal of 
Production Research 50(4): 1079-1095.

Banerjee SB, Iyer ES and Kashyap RK (2003) Corporate environmentalism: Antecedents and influence of industry type. Journal of Marketing 67(2): 106-122. DOI: 10.1509/jmkg.67.2.106.18604.

Bansal P and Hunter T (2003) Strategic explanations for the early adoption of ISO 14001. Journal of Business Ethics 46(3): 289-299. DOI: 10.1023/A:1025536731830.

Baumgärtner MK, Dwertmann DJG, Boehm SA, et al. (2015) Job satisfaction of employees with disabilities: The role of perceived structural flexibility. Human Resource Management 54(2): 323-343.

Bercovitz J, Jap SD and Nickerson JA (2006) The antecedents and performance implications of cooperative exchange norms. Organization Science 17(6): 677-775. DOI: 10.1287/orsc. 1060.0213 .

Boso N, Story VM, Cadogan JW, et al. (2013) Firm innovativeness and export performance: Environmental, networking, and structural contingencies. Journal of International Marketing 21(4): 62. DOI: 10.1509/jim.13.0052.

Bourn D and Prescott J (2002) A comparison of the nutritional value, sensory qualities, and food safety of organically and conventionally produced foods. Critical Reviews in Food Science and Nutrition 42(1): 1-34. DOI: 10.1080/10408690290825439.

Brettel M, Chomik C and Flatten TC (2015) How organizational culture influences innovativeness, proactiveness, and risk-taking: Fostering entrepreneurial orientation in SMEs. Journal of Small Business Management 53(4): 868-885. DOI:

10.1111/jsbm. 12108 .

Burns T and Stalker GM (1994) The Management of Innovation. Oxford University Press. Buysse K and Verbeke A (2003) Proactive environmental strategies: a stakeholder management perspective. Strategic Management Journal 24(5): 453-470. Available at: http://doi.wiley.com/10.1002/smj.299.

Cantor DE, Morrow PC and Blackhurst J (2015) An examination of how supervisors influence their subordinates to engage in environmental behaviors. Decision Sciences 46(4): 697-729. DOI: 10.1111/deci.12149.

Cardinal LB (2001) Technological innovation in the pharmaceutical industry: The use of organizational control in managing research and development. Organization Science 12(1): 19-36. DOI: 10.1287/orsc.12.1.19.10119.

Chang $\mathrm{CH}$ and Chen YS (2012) The determinants of green intellectual capital. Management Decision 50(1): 74-94. 
Chang CH and Chen YS (2013) Green organizational identity and green innovation. Management Decision 51(5): 1056-1070. DOI: 10.1108/md-09-2011-0314.

Chang DR and Park SB (2013) The effects of brand strategy and technological uncertainty on pioneering advantage in the multigenerational product market. Journal of Product Innovation Management 30(1): 82-95. DOI: 10.1111/j.1540-5885.2012.00988.x.

Chen J, Neubaum DO, Reilly RR, et al. (2015) The relationship between team autonomy and new product development performance under different levels of technological turbulence. Journal of Operations Management 33-34: 83-96. DOI: 10.1016/j.jom.2014.10.001.

Chen Y, Tang G, Jin J, et al. (2015) Linking market orientation and environmental performance: The influence of environmental strategy, employee's environmental involvement, and environmental product quality. Journal of Business Ethics 127(2): 479-500. DOI: 10.1007/s10551-014-2059-1.

Child J (1972) Organization structure and strategies of control: A replication of the aston study. Administrative Science Quarterly 17(2): 163-177. DOI: 10.2307/2393951.

Cho YN (2014) Different shades of green consciousness: The interplay of sustainability labeling and environmental impact on product evaluations. Journal of Business Ethics 128: 73-82. DOI: 10.1007/s10551-014-2080-4.

Csaszar FA (2013) An efficient frontier in organization design : Organizational structure as a determinant of exploration and exploitation. Organization Science 24(4): 1083-1101.

Cui AP, Walsh MF and Zou S (2014) The importance of strategic fit between host-home country similarity and exploration exploitation strategies on small and medium-sized enterprises' performance: A contingency perspective. Journal of International Marketing 22(4): 67-85. DOI: 10.1509/jim.14.0045.

Cummings LS (2008) Managerial attitudes toward environmental management within Australia, the People's Republic of China and Indonesia. Business Strategy and the Environment 17(1): 16-29. DOI: 10.1002/bse.515.

Dahlmann F, Brammer S and Millington A (2008) Environmental management in the United Kingdom: New survey evidence. Management Decision 33(3): 1-20. DOI: $10.1108 / 00251740810854159$.

Davis-Sramek B, Germain R and Krotov K (2015) Examining the process R\&D investmentperformance chain in supply chain operations: The effect of centralization. International Journal of Production Economics 167: 246-256. Available at: http://linkinghub.elsevier.com/retrieve/pii/S0925527315002042. 
Dawson JF (2014) Moderation in management research: What, why, when, and how. Journal of Business and Psychology 29(1): 1-19. DOI: 10.1007/s10869-013-9308-7.

De Jong MDT, Harkink KM and Barth S (2018) Making green stuff? Effects of corporate greenwashing on consumers. Journal of Business and Technical Communication 32(1): 77-113. DOI: $10.1177 / 1050651917729863$.

Delgado-Ceballos J, Aragón-Correa JA, Ortiz-de-Mandojana N, et al. (2012) The effect of internal barriers on the connection between stakeholder integration and proactive environmental strategies. Journal of Business Ethics 107(3): 281-293.

Donaldson L (1987) Strategy and Structural Adjustment to Regain Fit And Performance: In Defence Of Contingency Theory. Journal of Management Studies 24(1): 1-24. DOI: 10.1111/j.1467-6486.1987.tb00444.x.

Drazin R and de Ven AH Van (1985) Alternative forms of fit in contingency theory. Administrative Science Quarterly 30(4): 514-539. DOI: 10.2307/2392695.

Feng T, Zhao G and Su K (2014) The fit between environmental management systems and organisational learning orientation. International Journal of Production Research 52(10): 2901-2914. DOI: 10.1080/00207543.2013.857055.

Ferrón VV (2017) The dark side of ISO 14001 : The symbolic environmental behavior. European Research on Management and Business Economics 23(1): 33-39.

Flammer C (2013) Corporate social responsibility and shareholder reaction: The environmental awareness of investors. Academy of Management Journal 56(3): 758 781. DOI: 10.5465/amj.2011.0744.

Follows SB and Jobber D (2002) Environmentally responsible purchase behaviour: a test of a consumer model. European Journal of Marketing 34(5/6): 723-746. DOI: 10.1108/03090560010322009.

Fornell C and Larcker DF (1981) Evaluating structural equation models with unobservable variables and measurment error. Journal of Marketing 18(1): 39-50.

Frondel M, Horbach J and Rennings K (2007) End-of-pipe or cleaner production? An empirical comparison of environmental innovation decisions across OECD countries. Business Strategy and the Environment 16(8): 571-584.

Gadenne DL, Kennedy J and Mckeiver C (2009) An empirical study of environmental awareness and practices in SMEs. Journal of Business Ethics 84(1): 45-63. DOI: 10.1007/s10551-008-9672-9.

Galbraith JR (1973) Designing Complex Organizations. Addison-Wesley, Reading. Gallear D, Ghobadian A and He Q (2015) The mediating effect of environmental and ethical 
behaviour on supply chain partnership decisions and management appreciation of supplier partnership risks. International Journal of Production Research 53(21): 64556472. DOI: $10.1080 / 00207543.2014 .937010$.

Gardner W, Mulvey EP and Shaw EC (1995) Regression analysis of counts and rates: poission, overdispersed. Psychological Bulletin 118(3): 392-404.

González-Benito J (2008) The effect of manufacturing pro-activity on environmental management: An exploratory analysis. International Journal of Production Research 46(24): 7017-7038. DOI: 10.1080/00207540701474021.

Graham S and Potter A (2015) Environmental operations management and its links with proactivity and performance : A study of the UK food industry. International Journal of Production Economics 170: 146-159.

Gualandris J and Kalchschmidt M (2016) Developing environmental and social performance : the role of suppliers' sustainability and buyer - supplier trust. International Journal of Production Research 54(8): 2470-2486.

Hage J and Aiken M (1967) Relationship of centralization to other structural properties. Administrative Science Quarterly 12(1): 72-92. DOI: 10.2307/2391213.

Hair JF, Anderson RE, Tatham RL, et al. (1998) Multivariate Data Analysis. Upper Saddle River, NJ: Prentice hall. DOI: 10.1016/j.ijpharm.2011.02.019.

Hall J and Rosson P (2006) The impact of technological turbulence on entrepreneurial behavior, social norms and ethics: Three internet-based cases. Journal of Business Ethics 64(3): 231-248. DOI: 10.1007/s10551-005-5354-Z.

Hargreaves T (2016) Interacting for the environment: Engaging Goffman in proenvironmental action. Society and Natural Resources 29(1): 53-67. DOI: 10.1080/08941920.2015.1054978.

Hart SL (1995) A natural-resource-based view of the firm. Academy of Management Review 20(4): 986-1014.

Hausman JA, Hall BH and Griliches Z (1984) Econometric models for count data with an application to the patents-R\&D relationship. Econometrica 52(4): 909-938. DOI: $10.2307 / 1911191$.

Jaworski BJ and Kohli AK (1993) Market orientation: Antecedents and consequences. Journal of Marketing 57(3): 53-70.

Jiang RJ and Bansal P (2003) Seeing the need for ISO 14001. Journal of Management Studies 40(4): 1047-1067.

Johnstone N and Labonne J (2009) Why do manufacturing facilities introduce environmental 
management systems? Improving and/or signaling performance. Ecological Economics 68(3). Elsevier B.V.: 719-730. DOI: 10.1016/j.ecolecon.2008.06.003.

Joseph J, Klingebiel R and Wilson AJ (2016) Organizational structure and performance feedback: Centralization, aspirations, and termination decisions. Organization Science 27(5): 1065-1341. DOI: 10.1287/orsc.2016.1076.

Karim S, Carroll TN and Long CP (2016) Delaying change: Examining how industry and managerial turbulence impact structural realignment. Academy of Management Journal 59(3): 791-817. DOI: 10.5465/amj.2012.0409.

Keogh PD, Polonsky MJ, Keogh PD, et al. (2006) Environmental commitment : A basis for environmental entrepreneurship? Journal of Organizational Change Management 11(1): $38-49$.

Kim YJ, Kim WG, Choi HM, et al. (2019) The effect of green human resource management on hotel employees' eco-friendly behavior and environmental performance.

International Journal of Hospitality Management 76: 83-93. DOI:

10.1016/j.ijhm.2018.04.007.

King AA, Lenox MJ and Terlaak A (2005) The strategic use of decentralized institutions:

Exloring certifications with the ISO 14001 Management Standard. Academy of Management Journal 48(6): 1091-1106. DOI: 10.2307/20159731.

Klassen R and Angell L (1998) An international comparison of environmental management in operations: The impact of manufacturing flexibility in the U.S. and Germany. Journal of Operations Management 16(2-3): 177-194. DOI: 10.1016/S0272-6963(97)00037-5.

Kunapatarawong R and Martínez-ros E (2016) Towards green growth: How does green innovation affect employment? Research Policy 45(6): 1218-1232. DOI: 10.1016/j.respol.2016.03.013.

Leonidou LC, Fotiadis TA, Christodoulides P, et al. (2015) Environmentally friendly export business strategy: Its determinants and effects on competitive advantage and performance. International Business Review 24(5): 798-811. DOI:

10.1016/j.ibusrev.2015.02.001.

Lichtenstein S, Lichtenstein G and Higgs M (2017) Personal values at work: A mixedmethods study of executives' strategic decision-making. Journal of General Management 43(1): 15-23. DOI: 10.1177/0306307017719702.

Linnenluecke MK and Griffiths A (2010) Corporate sustainability and organizational culture. Journal of World Business 45(4): 357-366. DOI: 10.1016/j.jwb.2009.08.006.

Llach J, Alonso-Almeida MDM, García-Castellví A, et al. (2015) A fresh approach to context 
influence, development and performance in environmental management. Business Strategy and the Environment 24(8): 855-872. DOI: 10.1002/bse.1850.

López-Gamero MD, Claver-Cortés E and Molina-Azorín JF (2008) Complementary resources and capabilities for an ethical and environmental management: A qual/quan study. Journal of Business Ethics 82(3): 701-732. DOI: 10.1007/s10551-007-9587-x. López-Gamero MD, Pertusa-Ortega EM, Molina-Azorín JF, et al. (2016) Organizational antecedents and competitive consequences of environmental proactivity in the hotel industry. Journal of Sustainable Tourism 27(7): 949-970.

Lucas MT and Noordewier TG (2016) Environmental management practices and firm financial performance: The moderating effect of industry pollution-related factors. Intern. Journal of Production Economics 175(May 2016). Elsevier: 24-34. DOI: 10.1016/j.ijpe.2016.02.003.

Luo Y and Rui H (2009) An ambidexterity perspective toward multinational enterprises from emerging economies. Academy of Management Perspectives 23(4): 49-70. DOI: 10.5465/amp.23.4.49.

Martin WL, McKelvie A and Lumpkin GT (2016) Centralization and delegation practices in family versus non-family SMEs: A Rasch analysis. Small Business Economics 47(3): $755-769$.

McAdam R, Miller K and McSorley C (2019) Towards a contingency theory perspective of quality management in enabling strategic alignment. International Journal of Production Economics 207: 195-209. DOI: 10.1016/j.ijpe.2016.07.003.

McHugh PJ and Perrault E (2018) Accelerating time: The effect of social pressures and regulation on board gender diversity post-IPO. Journal of General Management 43(3): 95-105. DOI: $10.1177 / 0306307017752407$.

Menguc B, Auh S and Ozanne L (2010) The interactive effect of internal and external factors on a proactive environmental strategy and its influence on a firm's performance. Journal of Business Ethics 94(2): 279-298.

Mitra S and Datta PP (2014) Adoption of green supply chain management practices and their impact on performance: An exploratory study of Indian manufacturing firms. International Journal of Production Research 52(7): 2085-2107.

Montabon F, Sroufe R and Narasimhan R (2007) An examination of corporate reporting, environmental management practices and firm performance. Journal of Operations Management 25(5): 998-1014.

Narayanan S, Jayaraman V, Luo Y, et al. (2011) The antecedents of process integration in 
business process outsourcing and its effect on firm performance. Journal of Operations Management 29(1-2): 3-16. DOI: 10.1016/j.jom.2010.05.001.

Nunnally JC and Bernstein IH (1994) Psychometric Theory. McGraw-Hill, New York. Ogbeibu S, Emelifeonwu J, Senadjki A, et al. (2019) Technological turbulence and greening of team creativity, product innovation, and human resource management: Implications for sustainability. Journal of Cleaner Production 244: 118703.

Olson EM, Slater SF and Hult GTM (2005) The performance implications of fit among business strategy, marketing organization structure, and strategic behavior. Journal of Marketing 69(3): 49-65. DOI: 10.1509/jmkg.69.3.49.66362.

Ormazabal M and Sarriegi JM (2014) Environmental management evolution: Empirical evidence from Spain and Italy. Business Strategy and the Environment 23(2): 73-88. DOI: $10.1002 /$ bse. 1761 .

Pacheco DF and Dean TJ (2015) Firm responses to social movement pressures: A competitive dynamics perspective. Strategic Management Journal 36(7): 1093-1104.

Pal R and Altay N (2019) Identifying key success factors for social enterprises serving baseof-pyramid markets through analysis of value chain complexities. Journal of Business Logistics 40(2): 161-179. DOI: 10.1111/jbl.12212.

Peng YS and Lin SS (2008) Local responsiveness pressure, subsidiary resources, green management adoption and subsidiary's performance: Evidence from taiwanese manufactures. Journal of Business Ethics 79(1-2): 199-212. DOI: 10.1007/s10551-0079382-8.

Perez-Valls M, Cespedes-Lorente J and Moreno-Garcia J (2016) Green practices and organizational design as sources of strategic flexibility and performance. Business Strategy and the Environment 25(8): 529-544. DOI: 10.1002/bse.1881.

Podsakoff PM and Organ DW (1986) Self-reports in organizational research: Problems and prospects. Journal of Management 12(4): 531-544.

Porter ME (1985) Competitive Advantage: Creating and Sustaining Superior Performance. New York: Free press.

Prajogo D, Oke A and Olhager J (2016) Supply chain processes. International Journal of Operations \& Production Management 36(2): 220-238. DOI: 10.1108/IJOPM-03-20140129.

Purhoit HC (2012) Product positioning and consumer attitude towards eco-friendly labeling and advertisement an analytical study. Journal of Management Research 12(3): 153162. 
Quirin GD and Bower JL (1971) Managing the resource allocation process: A study of corporate planning and investment. The Journal of Finance 26(1): 208-209. DOI: $10.2307 / 2325773$.

Reichhart A and Holweg M (2008) Co-located supplier clusters: Forms, functions and theoretical perspectives. International Journal of Operations \& Production Management 28(1): 53-78. DOI: 10.1108/01443570810841103.

Rindfleisch A and Moorman C (2001) Utilization of and acquisition in new alliances: A strength-of-ties perspective. Journal of Marketing 65(2): 1-18.

Rousseau DM (1985) Issues of levels in organizational research: Multi-level and cross-level. Research in organizational behavior 7: 1-37.

Russo M V. and Fouts PA (1997) A resource-based perspective on corporate environmental performance and profitability. Academy of Management Journal 40(3): 534-559.

Schoonhoven CB (1981) Problems with contingency theory: Testing assumptions hidden within the language of contingency 'theory.'. Administrative science quarterly 26(3): 349-377. DOI: 10.2307/2392512.

Shane S (2003) A General Theory of Entrepreneurship: The Individual-Opportunity Nexus. Edward Elgar Publishing. DOI: 10.4337/9781781007990.

Shane S and Venkataraman S (2000) The promise of entrepreneurship as a field of research. Academy of Management Review 25(1): 217-226. DOI: 10.5465/AMR.2000.2791611.

Sharma S, Pablo AL and Vredenburg H (1999) Corporate environmental responsiveness strategies. Journal of Applied Behavioral Science 35(1): 87-108.

Siggelkow N and Levinthal DA (2003) Temporarily Divide to Conquer: Centralized, Decentralized, and Reintegrated Organizational Approaches to Exploration and Adaptation. Organization Science 14(6): 650-669. DOI: 10.1287/orsc.14.6.650.24840.

Singh N, Jain S and Sharma P (2015) Motivations for implementing environmental management practices in Indian industries. Ecological Economics 109: 1-8. DOI: 10.1016/j.ecolecon.2014.11.003.

Suarez F and Lanzolla G (2005) The half-truth of first-mover advantage. Harvard Business Review 83(4): 121-127.

Sweet S, Roome N and Sweet P (2003) Corporate environmental management and sustainable enterprise: The influence of information processing and decision styles. Business Strategy and the Environment 12(4): 265-277. DOI: 10.1002/bse.365.

Tamayo-Torres J, Ruiz-Moreno A and Lloréns-Montes FJ (2011) The influence of manufacturing flexibility on the interplay between exploration and exploitation: The 
effects of organisational learning and the environment. International Journal of Production Research 49(20): 6175-6198. DOI: 10.1080/00207543.2010.518989.

Tangpong C, Hung KT and Li J (2019) Toward an agent-system contingency theory for behavioral supply chain and industrial marketing research. Industrial Marketing Management 83: 134-147. DOI: 10.1016/j.indmarman.2018.10.003.

Theodosiou M and Katsikea E (2013) The export information system: An empirical investigation of its outcomes. Journal of International Marketing 21(3): 72-94. Thompson J (1967) Organizations in Action. McGraw Hill, New York.

Trumpp C, Endrikat J, Zopf C, et al. (2013) Definition, conceptualization, and measurement of corporate Environmental performance: A critical examination of a multidimensional construct. Journal of Business Ethics 126(2): 185-204. DOI: 10.1007/s10551-013-19318 .

Venkatraman N (1989) Strategic orientation of business enterprises: The construct, dimensionality, and measurement. Management Science 35(8): 942-962. DOI: 10.1287/mnsc.35.8.942.

Venkatraman N (1990) Performance implications of strategic coalignment: A methodological perspective. Journal of Management Studies 27(1): 19-41. DOI: 10.1111/j.14676486.1990.tb00751.x.

Vorhies DW and Morgan NA (2003) A configuration theory assessment of marketing organization fit with business strategy and its relationship with marketing performance. Journal of Marketing 67(1): 100-115. DOI: 10.1509/jmkg.67.1.100.18588.

Vroom VH and Philip WY (1973) Leadership and Decision-Making. University of Pittsburgh Pre.

Walker K, Ni N and Huo W (2014) Is the red dragon green? An examination of the antecedents and consequences of environmental proactivity in China. Journal of Business Ethics 125(1): 27-43. DOI: 10.1007/s10551-013-1903-z.

Wang C, Li X and Mao Z (2014) Green retailing practices: An exploratory comparison between Chinese and British retailers. Journal of General Management 39(2): 35-60. DOI: $10.1177 / 030630701303900203$.

Wang Z (2017) Firm visibility and voluntary environmental behavior: evidence from hydraulic fracturing. Land Economics 93(4): 654-666.

Weber K, Otto B and Österle H (2009) One size does not fit all-A contingency approach to data governance. Journal of Data and Information Quality 1(1): 1-27. DOI: $10.1145 / 1515693.1515696$. 
Wong CWY, Lai KH, Shang KC, et al. (2012) Green operations and the moderating role of environmental management capability of suppliers on manufacturing firm performance. International Journal of Production Economics 140(1): 283-294. DOI: 10.1016/j.ijpe.2011.08.031.

Wong EYC, Chan FFY and So S (2020) Consumer perceptions on product carbon footprints and carbon labels of beverage merchandise in Hong Kong. Journal of Cleaner Production 242: 118404.

Yu W and Ramanathan R (2015) An empirical examination of stakeholder pressures, green operations practices and environmental performance. International Journal of Production Research 53(21): 6390-6407. DOI: 10.1080/00207543.2014.931608.

Zailani SHM, Eltayeb TK, Hsu CC, et al. (2012) The impact of external institutional drivers and internal strategy on environmental performance. International Journal of Operations and Production Management 32(6): 721-745. DOI: 10.1108/01443571211230943.

Zhang L, Wang J and You J (2015) Consumer environmental awareness and channel coordination with two substitutable products. European Journal of Operational Research 241(1): 63-73.

Zhang L, Zhou H, Liu Y, et al. (2019) Optimal environmental quality and price with consumer environmental awareness and retailer's fairness concerns in supply chain. Journal of Cleaner Production 213: 1063-1079.

Zhao Y, Feng T and Shi H (2018) External involvement and green product innovation: The moderating role of environmental uncertainty. Business Strategy and the Environment 27(8): 1167-1180. DOI: 10.1002/bse.2060. 